\title{
CHEMICAL COMPOSITION OF AEROSOLS IN THE WEST COAST OF TAIWAN STRAIT, CHINA
}

\author{
Lijuan Zhao ${ }^{1 *}$, Chao Yang ${ }^{2}$ \\ ${ }^{1}$ Fujian Province Xiamen Environmental Monitoring Central Station, Xiamen, China - zhaolj.nuist@ foxmail.com \\ ${ }^{2}$ Xiamen Meteorological Bureau, Xiamen, China - chaoy999@163.com
}

Commission III, WG III/8

KEY WORDS: Chemical Composition, Water-soluble Ions, PM2.5, Air Pollution

\begin{abstract}
:
The chemical composition of aerosols was investigated using regular environmental air quality observation, a single particle aerosol mass spectrometer (SPAMS 0515) and an ambient ion monitor (URG 9000D) in Xiamen in 2018. The results showed that the annual average mass concentrations of $\mathrm{PM}_{2.5}$ was $22 \mu \mathrm{g} / \mathrm{m}^{3}$, and concentrations of water-soluble inorganic ions was $9.94 \mu \mathrm{g} / \mathrm{m}^{3}$ which accounted for $45.2 \%$ of $\mathrm{PM}_{2.5}$. $\mathrm{SO}_{4}{ }^{2-}, \mathrm{NO}_{3}{ }^{-}$and $\mathrm{NH}_{4}{ }^{+}$were main components of secondary reactions which contributed more than 77 percent of water-soluble inorganic ion concentration. As a coastal city, $\mathrm{Cl}^{-}$and $\mathrm{Na}^{+}$contributed 13.9 percent of water-soluble inorganic ion concentration. Based on single particle aerosol mass spectrometer analysing, mobile sources emission was the most important sources of particle matter which contributed over $30 \%$.
\end{abstract}

\section{INTRODUCTION}

In recent decades, rapid economic development and continuous progress of industrialization and urbanization in China have led to a rapid increase in the emission of air pollutants. Artificial factors, such as energy consumption, industrial production and urban construction, combined with natural factors, such as dust storms and climate change, have led to frequent air pollution events (Yin et al., 2014). With the public increasingly concerned about air pollution, the government has vigorously promoted air pollution prevention and control since 2013. Urban air quality has improved significantly since the implementation of the air pollution prevention and control action plan. Under this background, it is urgent to manage the emission sources of air pollution scientifically and pertinently. Chemical component analysis of particulate matter and pollution source tracing can provide strong technical support for the requirements of the management department.

Water-soluble inorganic ions are important chemical components of $\mathrm{PM}_{2.5}$, and a large number of studies have been carried out around the world (Deng et al., 2016; Huang et al., 2016; Liang et al., 2018; Luo et al., 2018; Masiol et al., 2015; Meng et al., 2016; Ming et al., 2017; Niu et al., 2016; Saxena et al., 2017; Szigeti et al., 2015; Tolis et al., 2015; Zhang et al., 2019). However, due to differences in geographical location, meteorological conditions, energy structure and industrial layout, results of these studies varied greatly. An et al., (2018) found that sulfate, nitrate and ammonium were the major components of secondary particles in the atmosphere and made important contributions to the aerosol extinction coefficient. Wang et al. (2016) found that different water-soluble inorganic ions had distinct diurnal variations.

In this study, the concentrations of water-soluble inorganic ions in Xiamen were obtained using Thermo Fisher Scientific URG 9000D in 2018. The concentrations and seasonal variations of water-soluble inorganic ions are showed in this paper. The results can improve our understanding of $\mathrm{PM}_{2.5}$ pollution in Xiamen and provide reference for improving environmental air quality in Xiamen.

\section{METHODOLOGY}

\subsection{Site Description and Sampling}

Continuous particulate mass concentrations and chemical compositions were measured at one location in Xiamen, China. Xiamen, located on the west coast of the Taiwan Strait, has a population of 4.11 million and an area of $1699.39 \mathrm{~km}^{2}$. The sampling site is set on the rooftops of the Xiamen Atmospheric Environment Monitoring Superstation (XAEMS; $118.1402^{\circ} \mathrm{E}$, $24.4386^{\circ} \mathrm{N}$ ). XAEMS, in a residential area, is located in the south of Xiamen Island, about $700 \mathrm{~m}$ from the coastline (Figure $1)$.

An ambient particulate matter monitor (Thermo Fisher Scientific TEOM Model 1405-DF), a single particle aerosol mass spectrometer (SPAMS 0515) and an ambient ion monitor (Thermo Fisher Scientific URG 9000D) were used to continuously monitor the mass concentrations of $\mathrm{PM}_{10}$ and $\mathrm{PM}_{2.5}$, mass concentrations of nine water-soluble inorganic ions $\left(\mathrm{Na}^{+}, \mathrm{Mg}^{2+}, \mathrm{K}^{+}, \mathrm{Ca}^{2+}, \mathrm{NH}_{4}{ }^{+}, \mathrm{F}_{-}, \mathrm{Cl}^{-}, \mathrm{NO}_{3}{ }^{-}\right.$and $\left.\mathrm{SO}_{4}{ }^{2-}\right)$, and single particle aerosol chemical composition. The data were collected hourly by the data acquisition system.

\footnotetext{
* corresponding author: Lijuan Zhao, zhaolj.nuist@ foxmail.com
} 


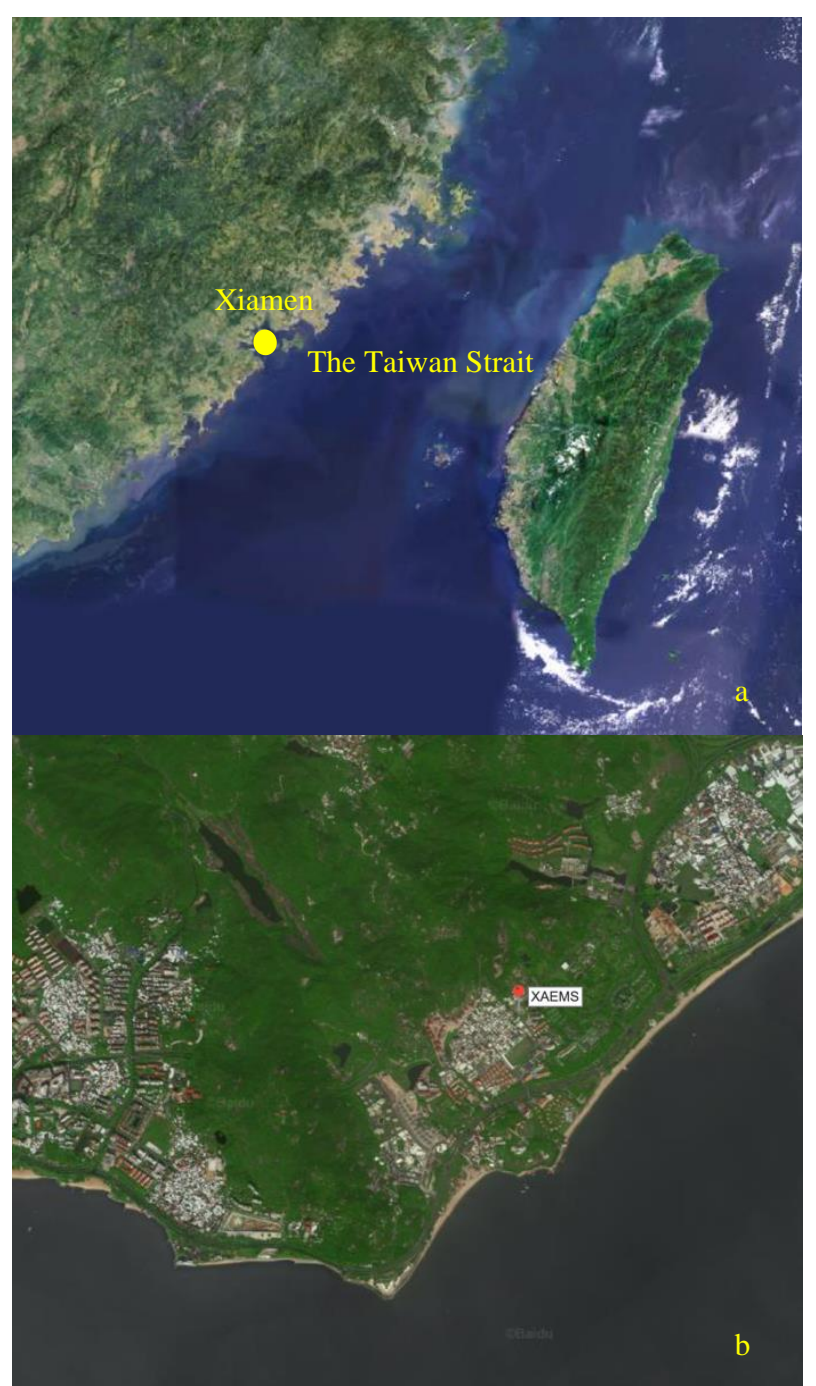

Figure 1. Geographical location map of Xiamen city (a) and XAEMS (b)

\subsection{Quality Assurance and Control}

The TEOM Model 1405-DF (Thermo Fisher Scientific, Waltham, MA) ambient particulate matter monitor is equipped with a Filter Dynamic Measurement System (FDMS), which can correct for semi volatile species evaporation from mass measurement filter surface. The instruments were operated at flow rates prescribed by manufacturer: $1.67 \mathrm{~L} / \mathrm{min}\left(\mathrm{PM}_{10-2.5}\right), 3$ $\mathrm{L} / \mathrm{min}\left(\mathrm{PM}_{2.5}\right)$, and $12 \mathrm{~L} / \mathrm{min}$ (bypass). TEOM instrument maintenance was performed every 20 days and consists of changing TEOM and FDMS filters, cleaning the PM10 inlet, checking for seal leaks in the mass transducer, flow audit and calibration, and instrument leak check.

The URG 9000 (Thermo Fisher Scientific) and SPAMS 0515 maintenance were performed monthly and consists of cleaning the inlet and tube, instrument leak check, etc.

To assure the highest quality data were used for analysis, the status log was filled out before and after maintenance to assure that the instrument conditions did not change due to operator intervention.

\section{RESULTS}

\section{1 $\mathbf{P M}_{2.5}$}

Daily concentration of $\mathrm{PM}_{2.5}$ at XAEMS in 2018 were in a range of $0.003 \sim 0.082 \mathrm{mg} / \mathrm{m}^{3}$, with an average and standard deviation of $0.022 \pm 0.012 \mathrm{mg} / \mathrm{m}^{3}$, reaching the China National Ambient Air Quality Standards (GB3095-2012) (grade II, 0.035 $\mathrm{mg} / \mathrm{m}^{3}$ ). The maximum monthly average concentration of $\mathrm{PM}_{2.5}$ occurred in February $\left(0.034 \mathrm{mg} / \mathrm{m}^{3}\right)$, and the maximum daily average concentration of $\mathrm{PM}_{2.5}$ occurred in March $(0.082$ $\mathrm{mg} / \mathrm{m}^{3}$ ), reaching the light pollution level of Air Quality Index (Figure 2). The seasonal concentration of $\mathrm{PM}_{2.5}$ in an order of winter > spring > autumn > summer, which can be explained by meteorological conditions. Higher $\mathrm{PM}_{2.5}$ concentration during winter and spring might be caused by stable atmospheric layer and lower mixing height. The stable atmosphere is conducive to the accumulation of air pollutants. In addition, heavy $\mathrm{PM}_{2.5}$ pollution occurs frequently in eastern China during winter and spring, and regional transmission of air pollutants has a great impact on local air quality. On the contrary, the dominant wind direction in Xiamen is southerly during summer, which is conducive to the diffusion of local air pollutants.

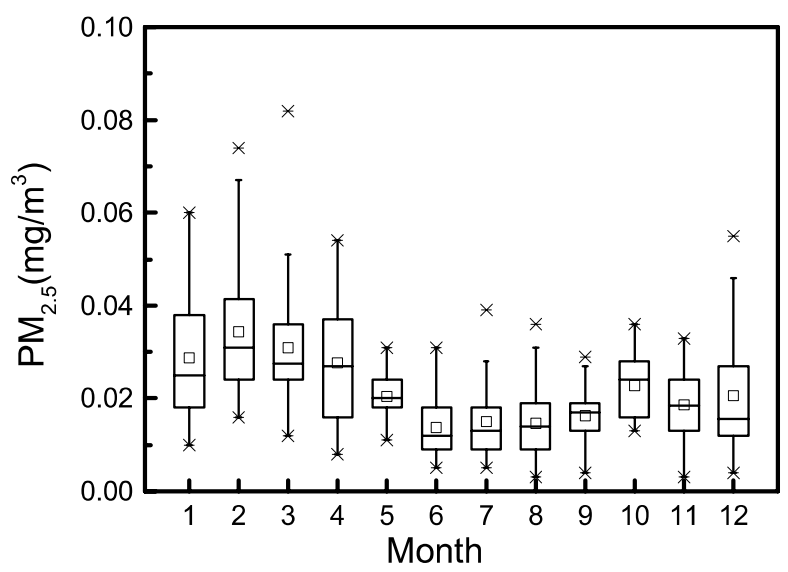

Figure 2. Monthly concentration of $\mathrm{PM}_{2.5}$

(The upper dash indicate the maximum, the lower dash indicate the minimum, the upper " $X$ " indicate the $99 \%$ value, the lower " $X$ " indicate the $1 \%$ value, the small square indicate the mean value, the upper edge of the box indicate the $75 \%$ value, the lower edge of the box indicate the $25 \%$ value, the horizontal line in the box indicate the median)

To illustrate the status of $\mathrm{PM}_{2.5}$ pollution in Xiamen, concentration of $\mathrm{PM}_{2.5}$ were compared with other cities over China and foreign countries (Table 1). Compared with other cities in China, $\mathrm{PM}_{2.5}$ concentration in Xiamen was lower than those values observed in inland cities and many coastal cities in China, such as Beijing $\left(51 \mu \mathrm{g} / \mathrm{m}^{3}\right)$, Xi'an $\left(63 \mu \mathrm{g} / \mathrm{m}^{3}\right)$, Chengdu $\left(51 \mu \mathrm{g} / \mathrm{m}^{3}\right)$, Wuhan $\left(49 \mu \mathrm{g} / \mathrm{m}^{3}\right)$, Dalian $\left(30 \mu \mathrm{g} / \mathrm{m}^{3}\right)$, Qingdao (34 $\left.\mu \mathrm{g} / \mathrm{m}^{3}\right)$, Shanghai $\left(36 \mu \mathrm{g} / \mathrm{m}^{3}\right)$, Ningbo $\left(33 \mu \mathrm{g} / \mathrm{m}^{3}\right)$, Guangzhou (35 $\left.\mu \mathrm{g} / \mathrm{m}^{3}\right)$, but much higher than Haikou $\left(18 \mu \mathrm{g} / \mathrm{m}^{3}\right)$. Due to similar geographical and climatic conditions, the concentration of $\mathrm{PM}_{2.5}$ in Xiamen was closest to Shenzhen $\left(26 \mu \mathrm{g} / \mathrm{m}^{3}\right)$. The annual $\mathrm{PM}_{2.5}$ concentration in Xiamen was similar with Italy (Veneto) and Greece (Thessaloniki).

\begin{tabular}{|c|c|c|c|}
\hline Study area & $\begin{array}{c}\text { Sampling } \\
\text { period }\end{array}$ & $\begin{array}{c}\mathrm{PM}_{2.5} \\
\left(\mu \mathrm{g} / \mathrm{m}^{3}\right)\end{array}$ & Reference \\
\hline $\begin{array}{c}\text { Xiamen, } \\
\text { China }\end{array}$ & 2018 & 22 & This study \\
\hline
\end{tabular}




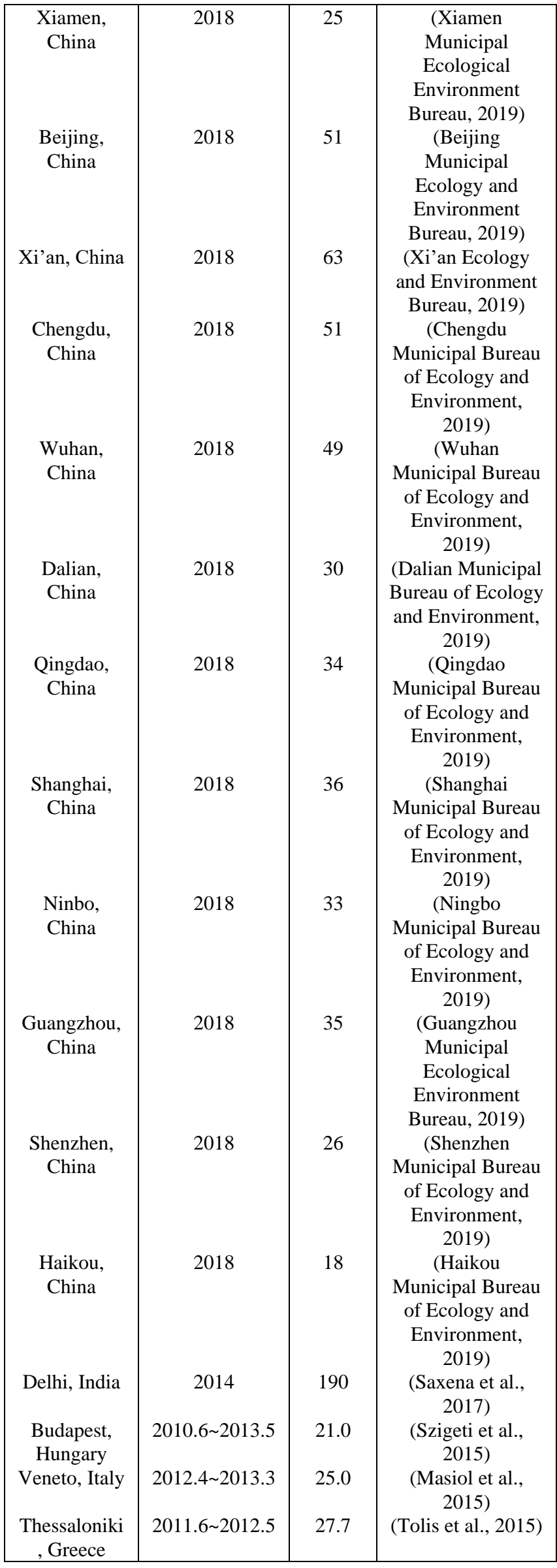

Table 1. Comparisons of $\mathrm{PM}_{2.5}$ concentrations in other cities

\subsection{Water-Soluble Inorganic Ions}

As showed in Table 2, the annual mean concentrations of total analysed water-soluble inorganic ions in $\mathrm{PM}_{2.5}$ in Xiamen was $9.94 \mu \mathrm{g} / \mathrm{m}^{3}$, accounting for $45.2 \%$ of the $\mathrm{PM}_{2.5}$ mass concentration. The concentrations of each water-soluble inorganic ions were observed in the order of $\mathrm{SO}_{4}{ }^{2-}>\mathrm{NH}_{4}{ }^{+}>\mathrm{NO}_{3}$ $>\mathrm{Na}^{+}>\mathrm{K}^{+}>\mathrm{F}^{-}>\mathrm{Cl}^{-}>\mathrm{Ca}^{2+}>\mathrm{Mg}^{2+}$. Sulfate, ammonium and nitrate, as typical secondary inorganic aerosols (SIAs), were the dominant water-soluble inorganic species, with the combined proportions accounting for $77.4 \%$ of the total analysed watersoluble inorganic ions concentrations. The SIAs usually derived from the secondary transformation of direct emission pollutant, such as sulfur dioxide $\left(\mathrm{SO}_{2}\right)$, nitrogen oxides $\left(\mathrm{NO}_{\mathrm{x}}\right)$, and ammonia $\left(\mathrm{NH}_{3}\right)$.

The average water-soluble inorganic ions concentrations were higher during winter and spring and lower during summer and autumn (Table 2), it is inconsistent with the seasonal variation characteristics in Nanjing (Zhang et al., 2019). The contributions of water-soluble inorganic ions in $\mathrm{PM}_{2.5}$ ranked in an order of summer $(52.0 \%)>$ spring $(49.0 \%)>$ autumn $(42.1 \%)$ $=$ winter $(42.1 \%)$. The proportions of the concentrations of SIAs to the total analysed water-soluble inorganic ions mass concentrations were ranked in the order of winter $(81.6 \%)>$ autumn $(77.5 \%)>$ spring $(75.6 \%)>$ summer $(72.4 \%)$. The lowest proportion of the concentrations of SIAs to the total analyzed water-soluble inorganic ions and highest contribution of water-soluble inorganic ions in $\mathrm{PM}_{2.5}$ in summer might because of the influence of the summer monsoon, which mainly come from the ocean, leading to a greater contribution of sea salt to water-soluble ions. The highest proportion of the concentrations of SIAs to the total analyzed water-soluble inorganic ions might cause by the surrounding and longdistance transmission of air pollutants. The reason for the lowest contributions of water-soluble inorganic ions in $\mathrm{PM}_{2.5}$ during winter and autumn is that there is less precipitation and dust has a greater impact on $\mathrm{PM}_{2.5}$. As a coastal city, $\mathrm{Cl}^{-}$and $\mathrm{Na}^{+}$contributed $13.9 \%$ of water-soluble inorganic ion concentration.

\begin{tabular}{|c|c|c|c|c|c|}
\hline Species & Annual & Winter & Spring & Summer & Autumn \\
\hline $\mathrm{SO}_{4}{ }^{2-}$ & 4.13 & 4.72 & 4.92 & 3.26 & 3.82 \\
$\mathrm{NO}_{3}^{-}$ & 1.14 & 1.36 & 1.73 & 0.94 & 0.69 \\
$\mathrm{Cl}^{-}$ & 0.38 & 0.54 & 0.53 & 0.23 & 0.31 \\
$\mathrm{~F}^{-}$ & 0.39 & 0.22 & 0.41 & 0.76 & 0.21 \\
$\mathrm{NH}_{4}^{+}$ & 2.42 & 3.47 & 3.04 & 1.27 & 1.80 \\
$\mathrm{Na}^{+}$ & 0.70 & 0.69 & 0.72 & 0.64 & 0.77 \\
$\mathrm{~K}^{+}$ & 0.54 & 0.43 & 1.10 & 0.34 & 0.34 \\
$\mathrm{Mg}^{2+}$ & 0.05 & 0.06 & 0.10 & 0.03 & 0.04 \\
$\mathrm{Ca}^{2+}$ & 0.18 & 0.20 & 0.29 & 0.09 & 0.16 \\
$\mathrm{SUM}_{\text {SIA }}$ & 7.69 & 9.55 & 9.69 & 5.47 & 6.32 \\
SUM $_{\text {ions }}$ & 9.94 & 11.70 & 12.83 & 7.55 & 8.15 \\
$\mathrm{SUM}_{\mathrm{SII}} /$ SUUM $_{\text {ions }}$ & 77.4 & 81.6 & 75.6 & 72.4 & 77.5 \\
$(\%)$ & & & & & \\
$\mathrm{SUM}_{\text {ions }} / \mathrm{PM}_{2.5}$ & 45.2 & 42.1 & 49.0 & 52.0 & 42.1 \\
$(\%)$ & & & & & \\
\hline
\end{tabular}

SUMsia: sum of $\mathrm{SO}_{4}{ }^{2-}, \mathrm{NO}_{3}{ }^{-}$and $\mathrm{NH}_{4}{ }^{+}$; SUMions: sum of all analysed water-soluble inorganic ions.

Table 2. Annual and seasonal mean concentrations of watersoluble inorganic ions in $\mathrm{PM}_{2.5}$ in Xiamen $\left(\mu \mathrm{g} / \mathrm{m}^{3}\right)$

The monthly and seasonal trends of water-soluble inorganic ions were obviously different (figure 3). Influenced by atmospheric oxidizing, monthly variations of $\mathrm{SO}_{4}{ }^{2-}$ to the total 
analyzed water-soluble inorganic ions exhibited the maximum in September and minimum in March. Sulfate mainly forms from the photochemical oxidation of sulfur-containing precursors, such as $\mathrm{H}_{2} \mathrm{~S}$ and $\mathrm{SO}_{2}$ (Kleeman et al., 2000). Ozone concentration in Xiamen was relatively high in September, high concentration of ozone could aggravate photochemical activity, which in turn increase sulfate formation. The highest proportion of $\mathrm{NH}_{4}^{+}$to the total analyzed water-soluble inorganic ions was observed in January, resulting from biomass burning, microbe metabolism and agricultural activity (Yin et al., 2014).

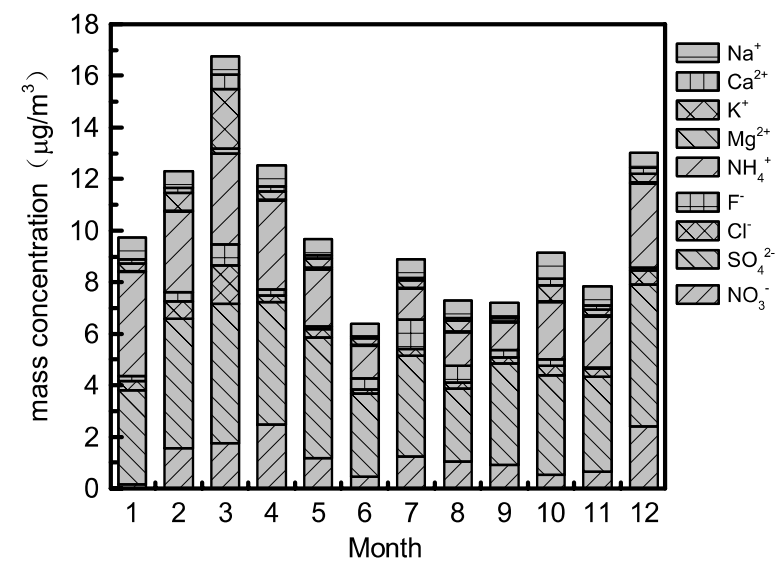

Figure 3. Monthly variations in water-soluble inorganic ions

Table 3 showed comparison between our SIAs results and previous studies. Except for Wuhan $(58.0 \%)$, SIAs accounted for $31.9 \% \sim 47.9 \%$ of $\mathrm{PM}_{2.5}$ concentration in Chinese cities. $\mathrm{PM}_{2.5}$ mass concentrations in Veneto (Italy) and Thessaloniki (Greece) were similar to that in Xiamen, and SIAs accounted for about $35 \%$ of $\mathrm{PM}_{2.5}$ mass concentration in these three cities. The combined percentages of SIAs in $\mathrm{PM}_{2.5}$ were relatively lower in Delhi (India) and Budapest (Hungary). The differences in contribution of SIAs to $\mathrm{PM}_{2.5}$ among cities might because of variations in energy structure, economic structure, geological condition, meteorological characteristics and population density.

\begin{tabular}{|c|c|c|c|c|c|}
\hline Study area & $\begin{array}{l}\text { Sampling } \\
\text { period }\end{array}$ & $\begin{array}{l}\mathrm{PM}_{2.5} \\
\left(\mu \mathrm{g} / \mathrm{m}^{3}\right)\end{array}$ & $\begin{array}{l}\mathrm{SUM}_{\mathrm{SIA}} \\
\left(\mu \mathrm{g} / \mathrm{m}^{3}\right)\end{array}$ & $\begin{array}{c}\mathrm{SUM}_{\mathrm{SIA}} / \mathrm{PM}_{2.5} \\
(\%)\end{array}$ & Reference \\
\hline $\begin{array}{l}\text { Xiamen, } \\
\text { China }\end{array}$ & 2018 & 22 & 7.69 & 35.0 & this study \\
\hline Zibo, China & $\begin{array}{c}2006.3 \\
\sim 2007.2\end{array}$ & 164.4 & 59.17 & 36.0 & $\begin{array}{l}\text { (Luo et al., } \\
2018 \text { ) }\end{array}$ \\
\hline $\begin{array}{l}\text { Handan, } \\
\text { China }\end{array}$ & $\begin{array}{c}2013 \\
\sim 2014\end{array}$ & 139.4 & 58.8 & 42.2 & $\begin{array}{c}\text { (Meng et al., } \\
2016)\end{array}$ \\
\hline Baoji, China & $\begin{array}{c}2012.3 \\
\sim 2013.3\end{array}$ & 132 & 42.1 & 31.9 & $\begin{array}{l}\text { (Niu et al., } \\
\text { 2016) }\end{array}$ \\
\hline $\begin{array}{l}\text { Shanghai, } \\
\text { China }\end{array}$ & $\begin{array}{c}2013.9 \\
\sim 2014.8\end{array}$ & 94.6 & 40.63 & 42.9 & $\begin{array}{c}\text { (Ming et al., } \\
\text { 2017) }\end{array}$ \\
\hline $\begin{array}{l}\text { Nanjing, } \\
\text { China }\end{array}$ & $\begin{array}{c}2014.12 \\
\sim 2015.11\end{array}$ & 94.4 & 33.45 & 35.4 & $\begin{array}{l}\text { (Zhang et } \\
\text { al., 2019) }\end{array}$ \\
\hline Hefei, China & $\begin{array}{c}2012.9 \\
\sim 2013.8\end{array}$ & 86.29 & 38.52 & 44.6 & $\begin{array}{c}\text { (Deng et al., } \\
2016)\end{array}$ \\
\hline $\begin{array}{l}\text { Wuhan, } \\
\text { China }\end{array}$ & $\begin{array}{c}2013.1 \\
\sim 2013.12\end{array}$ & 65 & 37.73 & 58.0 & $\begin{array}{l}\text { (Huang et } \\
\text { al., 2016) }\end{array}$ \\
\hline $\begin{array}{l}\text { Zhuhai, } \\
\text { China }\end{array}$ & $\begin{array}{c}2015.1 \\
\sim 2016.1\end{array}$ & 36.4 & 17.42 & 47.9 & $\begin{array}{c}\text { (Liang et al., } \\
\text { 2018) }\end{array}$ \\
\hline Delhi, India & 2014 & 190 & 45.53 & 24.0 & $\begin{array}{l}\text { (Saxena et } \\
\text { al., 2017) }\end{array}$ \\
\hline Veneto, Italy & $\begin{array}{c}2012.4 \\
\sim 2013.3\end{array}$ & 25 & 8.1 & 32.4 & $\begin{array}{l}\text { (Masiol et } \\
\text { al., 2015) }\end{array}$ \\
\hline $\begin{array}{l}\text { Budapest, } \\
\text { Hungary }\end{array}$ & $\begin{array}{c}2010.6 \\
\sim 2013.5\end{array}$ & 21 & 6.2 & 29.5 & $\begin{array}{l}\text { (Szigeti et } \\
\text { al., 2015) }\end{array}$ \\
\hline $\begin{array}{c}\text { Thessaloniki, } \\
\text { Greece }\end{array}$ & $\begin{array}{c}2011.6 \\
\sim 2012.5 \\
\end{array}$ & 27.7 & 10.2 & 36.8 & $\begin{array}{c}\text { (Tolis et al., } \\
2015)\end{array}$ \\
\hline
\end{tabular}

SUMSIA: sum of $\mathrm{SO}_{4}^{2-}, \mathrm{NO}_{3}{ }^{-}$and $\mathrm{NH}_{4}^{+}$.

Table 3. Comparisons of $\mathrm{PM}_{2.5}$, SUMsia concentrations in other cities

\subsection{Source of Particulate Matter}

Based on the single particle mass spectrometry detection results and the characteristic source spectra of local air pollution sources, the source analysis of local particles can be carried out. Mobile sources emission was the most important sources of particle matter which contributed over 30\% (Figure 4). Coal combustion was the second largest source, accounting for about $13 \%$. Biomass combustion accounted for about $7 \%$, and the percentages of dust and industrial process were around 5\%. The proportion of sea salt was the least, but the seasonal variation of sea salt proportion is the most significant, with proportion changing from $1.6 \%$ in winter to $6.6 \%$ in summer.

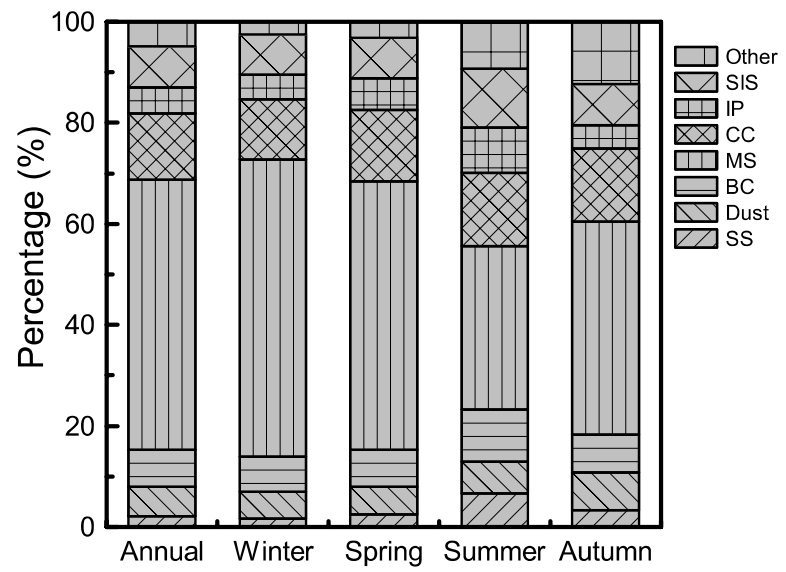

Figure 4. Seasonal variations in the source of particulate matter (SS: sea salt, BC: biomass combustion, MS: mobile source, CC: coal combustion, IP: industrial process, SIS: secondary inorganic source)

\section{CONCLUSIONS}

The chemical composition of aerosols in 2018 was discussed. The results showed that the annual average mass concentrations of $\mathrm{PM}_{2.5}$ was $22 \mu \mathrm{g} / \mathrm{m}^{3}$. This value was lower than those values observed in inland cities and many coastal cities in China, suggesting that the fine particle pollution was relatively light in Xiamen. The concentration of water-soluble inorganic ions was $9.94 \mu \mathrm{g} / \mathrm{m}^{3}$ which accounted for $45.2 \%$ of $\mathrm{PM}_{2.5}$. The average water-soluble inorganic ions concentrations were higher during winter and spring and lower during summer and autumn. $\mathrm{SO}_{4}{ }^{2-}$, $\mathrm{NO}_{3}{ }^{-}$and $\mathrm{NH}_{4}{ }^{+}$were main components of secondary reactions which contributed more than 77 percent of water-soluble inorganic ion concentration. As a coastal city, $\mathrm{Cl}^{-}$and $\mathrm{Na}^{+}$ contributed 13.9 percent of water-soluble inorganic ion concentration. Based on single particle aerosol mass spectrometer analysing, mobile sources emission was the most important sources of particle matter which contributed over $30 \%$. The proportion of sea salt was the least, but the seasonal variation of sea salt proportion is the most significant.

\section{ACKNOWLEDGEMENTS}

This work was supported by the Xiamen Science and Technology Beneficent Project (3502Z20174053).

\section{REFERENCES}

An, J.L., Cao, Q.M., Zou, J.N., Wang, H.L., Duan, Q., Shi, Y.Z., Chen, C., Wang, J.X., 2018. Seasonal variation in water-soluble ions in airborne particulate deposition in the suburban Nanjing 
area, Yangtze River Delta, China, during haze days and normal days. Arch. Environ. Contam. Toxicol., 74, 1-15.

Beijing Municipal Ecology and Environment Bureau, 2019. Beijing ecology and environment statement 2018 .

Chengdu Municipal Bureau of Ecology and Environment, 2019. 2018 Chengdu ecological and environmental bulletin.

Dalian Municipal Bureau of Ecology and Environment, 2019. 2018 Dalian ecological and environmental bulletin .

Deng, X.L., Shi, C.E., Wu, B.W., Yang, Y.J., Jin, Q., Wang, H.L., Zhu, S., Yu, C.X., 2016. Characteristics of the watersoluble components of aerosol particles in Hefei, China. $J$. Environ. Sci., 42, 32-40.

Guangzhou Municipal Ecological Environment Bureau, 2019. 2018 Guangzhou environmental quality bulletin.

Haikou Municipal Bureau of Ecology and Environment, 2019. 2018 Haikou environmental bulletin.

Huang, T., Chen, J., Zhao, W.T., Cheng, J.X., Cheng, S.G., 2016. Seasonal variations and correlation analysis of watersoluble inorganic ions in $\mathrm{PM}_{2.5}$ in Wuhan, 2013. Atmosphere, 7. https://doi.org/10.3390/atmos7040049

Kleeman, M.J., Schauer, J.J., Cass, G.R., 2000. Size and composition distribution of fine particulate matter emitted from motor vehicles. Environ. Sci. Technol., 34, 1132-1142.

Liang, Z.B., Zhao, X.F., Chen, J.Y., Gao, L., Zhu, A.P., Wang, Z.W., Li, S.H., Shan, J.J., Long, Y.M., Yan, C., Zhang, K. 2018. Seasonal characteristics of chemical compositions and sources identification of PM2.5 in Zhuhai, China. Environ. Geochem. Health., https://doi.org/10.1007/s10653-018-0164-2

Luo, Y.Y., Zhou, X.H., Zhang, J.Z., Xiao, Y., Wang, Z., Zhou, Y., Wang, W.X., 2018. $\mathrm{PM}_{2.5}$ pollution in a petrochem- ical industry city of northern China: seasonal variation and source apportionment. Atmos. Res., 212, 285-295.

Masiol, M., Benetello, F., Harrison, R.M., Formenton, G., De Gaspari, F., Pavoni, B., 2015. Spatial, seasonal trends and transboundary transport of $\mathrm{PM}_{2.5}$ inorganic ions in the Veneto region (northeastern Italy). Atmos. Environ., 117, 19-31.

Meng, C.C., Wang, L.T., Zhang, F.F., Wei, Z., Ma, S.M., Ma, X., Yang, J., 2016. Characteristics of concentrations and watersoluble inorganic ions in PM2.5 in Handan City, Hebei province, China. Atmos. Res., 171, 133-146.

Ming, L.L., Jin, L., Li, J., Fu, P.Q., Yang, W.Y., Liu, D., Zhang, G., Wang, Z.F., Li, X.D., 2017. PM 2.5 in the Yangtze River Delta, China: chemical compositions, seasonal variations, and regional pollution events. Environ. Pollut., 223, 200-212.

Ningbo Municipal Bureau of Ecology and Environment, 2019. 2018 Ningbo ecological and environmental bulletin.

Niu, X.Y., Cao, J.J., Shen, Z.X., Ho, S.S.H., Tie, X.X., Zhao, S.Y., Xu, H.M., Zhang, B.T., Huang, R.J., 2016. PM $_{2.5}$ from the Guanzhong plain: chemical composition and implications for emission reductions. Atmos. Environ., 147, 458-469.
Qingdao Municipal Bureau of Ecology and Environment, 2019. 2018 Qingdao ecological and environmental bulletin.

Saxena, Mohit., Sharma, A., Sen, A., Saxena, P., Saraswati, Y., Mandal, T.K., Sharma, S.K., Sharma, C., 2017. Water soluble inorganic species of PM10 and PM2.5 at an urban site of Delhi, India: seasonal variability and sources. Atmos. Res., 184, 112125 .

Shanghai Municipal Bureau of Ecology and Environment, 2019. 2018 Shanghai ecological and environmental bulletin.

Shenzhen Municipal Bureau of Ecology and Environment, 2019. 2018 Shenzhen environmental quality bulletin.

Szigeti, T., Ovari, M., Dunster, C., Kelly, F.J., Lucarelli, F., Zaray, G., 2015. Changes in chemical composition and oxidative potential of urban PM2.5 between 2010 and 2013 in Hungary. Sci. Total. Environ., 518, 534-544.

Tolis, E.I., Saraga, D.E., Lytra, M.K., Papathanasiou, A.C., Bougaidis, P.N., Prekas-Patronakis, O.E., Ioannidis, I.I., Bartzis, J.G., 2015. Concentration and chemical composition of $\mathrm{PM}_{2.5}$ for a one-year period at Thessaloniki, Greece: a comparison between city and port area. Atmos. Environ., 113, 197-207.

Wuhan Municipal Bureau of Ecology and Environment, 2019. 2018 Wuhan ecological and environmental bulletin.

Xiamen Municipal Ecological Environment Bureau, 2019. Xiamen environmental quality bulletin in 2018.

Xi'an Ecology and Environment Bureau, 2019. Xi'an environmental quality bulletin in 2018.

Yin, L.Q., Niu, Z.C., Chen, X.Q., Chen, J.S., Zhang, F.W., Xu, L.L., 2014. Characteristics of water-soluble inorganic ions in $\mathrm{PM}_{2.5}$ and $\mathrm{PM}_{2.5-10}$ in the coastal urban agglomeration along the Western Taiwan Strait region, China. Environ. Sci. Pollut. Res., $21,5141-5156$.

Zhang, X., Zhao, X., Ji, G., Ying, R., Shan, Y., Lin, Y., 2019. Seasonal variations and source apportionment of water-soluble inorganic ions in $\mathrm{PM}_{2.5}$ in Nanjing, a megacity in southeastern China. J. Atmos. Chem., http://doi.org/10.1007/s10874-01909388-z. 